\title{
To be independent or not to be independent, that is the question
}

\section{BBC-UK Government relations, 2016}

\author{
Jay G. Blumler
}

Published online: 18 July 2016

(C) The Author(s) 2016. This article is available at SpringerLink with Open Access.

It may seem strange to outsiders that this question should be asked. After all, the $\mathrm{BBC}$ has long enjoyed an international reputation for its - especially its journalism's - independence from political influence. It was, for example, the model for German public service broadcasting, introduced by the Allied powers after World War II in the three Western occupation zones. Hugh Greene, who was responsible for the establishment of the central broadcasting corporation in Northwest Germany (and later became Director General of the BBC), resisted all attempts by politicians to take control of it.

The influences likely to affect the answer are multi-faceted and complex. The outcome will eventually depend on the terms of the next Royal Charter of the BBC, due to run for 11 years from January 2017, the government's prospectus for which was published in a White Paper in May 2016 (Department for Culture, Media and Sport 2016a). This article examines associated BBC-government relations successively in historical, political and systemic (about the BBC's vulnerabilities and defenses) contexts, after which the White Paper's proposals for the future of the BBC will be successively outlined, explained and evaluated.

\section{Until recent times}

Historically, the political independence of the BBC was underpinned by strong structural and normative sources of support. Structurally, Kelly (1983) classified

Prof. J. G. Blumler, PhD ( $\varangle)$

Leeds, United Kingdom

E-Mail: jayblumler@sky.com

Prof. J. G. Blumler, PhD

College Park, Maryland, USA 
British broadcasting as a "formally autonomous system", not a "politics in" or a "politics over" one. Hallin and Mancini (2004) placed the UK in their North Atlantic liberal media system model, not a democratic corporatist or a polarized pluralist one, due in part to the BBC's distance from political authority. Hanretty (2011) lists a number of independence-safeguarding features of the BBC's situation as follows:

- determination of the roles and powers of the BBC in a Royal Charter (rather than by parliamentary legislation) usually at ten-year intervals,

- funding by a license fee payable by all television set holders, not by government grants or commercial advertising,

- the role of a supervisory Trust (previously the Board of Governors) in part to defend the BBC's independence should it come under threat,

- all executive appointments made by the BBC itself - other than the Director General (appointed by the Trust),

- that "Authority over journalists is exercised primarily by fellow journalists" (quoting from Hallin and Mancini 2004, p. 35),

- editorial codes and guidelines formulated and enforced by the BBC.

Normatively, the principle of BBC independence has been regarded, highly and widely throughout Britain, as a prized essential for maintenance of a trustworthy broadcasting service in the public interest. It has consequently served as an important shield against attempted political interference with BBC decisions.

\section{The politics of broadcasting organization and performance}

All that said, BBC independence is not and never has been an absolute "given". Hanretty (2011) terms it a "scale variable" instead. As Smith (1973, p. 140) once put it, "The autonomy of a broadcasting institution is a delicate flower, nervously planted, tenderly nurtured and easily plucked up by the roots." And as the medium with by far the greatest and most frequent reach to voters, though the influence of social media is growing fast, how television reports politics is inescapably relevant to power - in circumstances where politicians and journalists have different and sometimes conflicting obligations, priorities, values and interests. Attempts by politicians to influence how the media (especially television, especially BBC television news) cover their affairs are therefore in a sense natural and understandable. And in a liberal democracy, particularly one in which journalists independently set news agendas and fashion story frames, governments may sometimes regard themselves as facing and having to contend with two oppositions: their partisan rivals and the journalistic fraternity. (A vivid expression of this outlook may be seen in the account by Bernard Ingham, 1991, of his time as Margaret Thatcher's Press Officer.) Consequently, the BBC has always had somehow to manage its relations with government and to keep abreast of its concerns. One of the functions of the Political Advisor to its Director General had been to liaise with the UK's main political parties. BBC executives have often met, even wined and dined, political 
leaders to keep in touch and to stay on mutually understanding and amicable terms with them whenever possible without compromising the Corporation's integrity.

Even so, the BBC's relationship with government has been punctuated throughout its existence by a series of high-octane rows and conflicts, accompanied at times by real threats to its independence. According to Jean Seaton, the BBC's official historian $(2015,2016)$, these should not always be regarded as unfortunate events. The BBC would be a state broadcaster if it was not involved in such rows from time to time. They were normal, even a sign of hope. At any rate, both Labour and Conservative Prime Ministers (e. g. Harold Wilson and Margaret Thatcher), following dissatisfaction with $\mathrm{BBC}$ reporting (of the 1974 general election campaigns and of the conflict between Catholics and Protestants in Northern Ireland, respectively) used their power to install as Chairmen of the Board of Governors individuals whom they hoped would foster more understanding and sympathetic coverage of their affairs. In 2002, both the then Chairman and Director General of the BBC were obliged to resign their posts in response to the findings of an official enquiry into government-alleged inaccuracies in the BBC's reporting of its case for embarking on the Iraq war. In the 1970s, the Labour government imposed short-term licensefee settlements on the $\mathrm{BBC}$, partly in response to perceptions of its anti-government bias. In the mid 1980's, ideological leanings prompted Mrs. Thatcher to set up a Committee on Financing the BBC, chaired by a pro-market economist, Sir Alan Peacock, to consider the case for funding it entirely or partially by the sale of advertising. In the background of some disputes (e. g. over the BBC's willingness to present a broadcast by Hugh Gaitskell in opposition to the government's military involvement against Egypt during the Suez crisis of 1956), has been a threat to invoke a reserve government right, written into an Agreement that accompanies BBC Charters, to prohibit or require broadcasts in emergency conditions.

The BBC's responses to past threats have been mixed, including both stout resistance (e. g. over Suez) and a marshalling of supportive allies (e.g. over advertising finance) but also corporate caution (e.g. in the 1960s by bringing to an early end the broadcasting of That Was the Week That Was, an immensely popular series of highly satirical commentary on political events and personalities). Writing in 1979, p. 246, Briggs declared that "Broadcasting in doubt or under threat [had] become more cautious than it was in the 1960s." Smith (1979, p. 40) also concluded that, "Caution [had] grown over [British] broadcasting slowly like lichen over standing stones", sometimes lasting for years inside the organization.

Throughout this period, however, even when the BBC gave ground or suffered setbacks, the very principle of its editorial independence was never questioned or jettisoned and always emerged as the accepted bedrock of the Corporation's operations. In contrast, the present UK government's approach to its review of the BBC's Charter, seemed to pose a more fundamental threat to that principle itself. The review was launched by the publication in July 2015 of a Green Paper (Department for Culture, Media and Sport 2015), in which the government raised four sets of questions about the BBC's future mission, its scale and scope, its funding, and its governance and regulation. Supporters and critics of the BBC alike anticipated (on the one side) and feared (on the other) a government intention to undertake a rootand-branch overhaul of the Corporation's structure, role and resources. 
Although some months of consultation, public discussion and BBC-government negotiation would precede publication of a definitive version of the government's proposals in a White Paper, the cards were presumed by many to be stacked against $\mathrm{BBC}$ interests and traditions. This interpretation was not only based on the tenor of the Green Paper, which Barnett (2015) described as "an unprecedented and fullfrontal assault on the BBC's role at the heart of Britain's cultural and democratic life". Other omens seemed to support it. There had been two recent precedents when, in 2010 and 2015, the Chancellor of the Exchequer had abruptly and more or less arbitrarily imposed license fee settlements that significantly reduced the BBC's income, necessitating closure of one of its broadcast channels (youth channel BBC3), while increasing its spending commitments - on the World Service, which had hitherto been funded by the Foreign Office, and to subsidise free licenses for viewers aged 75 and over. And a government promise in 2015 annually to link the license fee to a cost of living index for at least five years was contingent upon eventual decisions about the BBC's scale and scope in the next Charter period. Unsurprisingly, the BBC's Director of Strategy complained that the government was tending to treat the BBC as like a department of state (Edwardes 2015). Moreover, John Whittingdale, the Minister for Culture, Sport and the Media, having at one point questioned whether the BBC should be all things to all people and suggested its approach should be more targeted, was said by some to be "downright hostile to the BBC" (Babbs 2016); opposed to mass popular programming on BBC1 (television) and Radio's 1 and 2 (Patten, 2016); was determined to "kill off the Beeb" (Ianucci 2016); and had "made no secret of his wish to overhaul the BBC from top to bottom" (Attenborough, quoted in Plunkett 2016, May 3). In a flurry of mixed signals, Whittingdale sometimes appeared to confirm these interpretations, for example, when characterizing the $\mathrm{BBC}$ as a $£ 4$ bn market intervention and stating at a public meeting that the BBC sometimes drove him "insane", tempting him to "abolish" it! Veteran BBC radio presenter, Sue MacGregor (as quoted in Plunkett 2016, March 11), epitomized the alarms when she declared that after four decades of work in broadcasting, today "is the most dangerous time for the BBC".

How well-placed was the $\mathrm{BBC}$ to counter the feared threats to its role and independence? Briggs had concluded after analysing the main crises in BBC-government relations up to his time of writing $(1979$, p. 191) that they had "reveal[ed] both the vulnerability of the BBC to external pressure and the system of defenses, which it has been able to construct, even when mistakes have been made." But at the end of the 1970s, an unalloyed public service model of British broadcasting had prevailed, including the advertising-funded but strictly regulated Independent Television service as well as the BBC. Since then, as natural history broadcaster, David Attenborough (quoted in Plunkett 2016, May 3), has put it:

The whole [of broadcasting] has changed beyond recognition. When I joined the $\mathrm{BBC}$, it was like a civil service, a monopoly, and there's no comparison to what it is now.

Since then, a combination of external sources of pressure and internally generated problems have probably deepened the BBC's vulnerability, on the one hand, and made it more difficult to determine and follow a public service path, on the other. 


\section{The external context}

For one thing, communication and media abundance has exploded, with a multiplicity of channels, news services and reception devices giving viewers far greater choice of what, when, where and how to watch programmes. In this situation, the $\mathrm{BBC}$ is surrounded by a host of programme-making and distributing competitors including mainstream channels with reduced or no public service obligations, plus a number of cable, satellite and streamed providers, as well as the entry into the communication field of non-state actors such as Apple. The level of its funding, which has fallen by $20 \%$ since 2010-11 (Enders Analysis 2015), has been increasingly outstripped by Sky Television. In consequence, the BBC has been thrust willynilly into an intense competition for "the attention and time" of would-be viewers, "a zero-sum game", which it could be in danger of losing (Naughton 2016). The commercial companies have been lobbying hard for tighter controls on the BBC, for a reduction in its scope, and for limits on what it can broadcast. And after the Green Paper was published, the Minister for Culture, Media and Sport appointed a number of commercial company leaders to an "advisory panel" for contributions to Charter Review issues.

Over the same period, the BBC has been surrounded by a host of voices, clamouring for coverage of messages on their own terms, many of them persistently and sophisticatedly organized to achieve their communication goals. This has been a product of various mutually reinforcing developments: political fragmentation, especially of the UK party system; a proliferation of campaigning cause and interest groups that regard effective mediated communications as essential weapons in their political armouries; evolution of the Internet into "a veritable cornucopia of political perspectives" (Perloff 2015); the professionalization of major parties' communication organization, strategies and tactics - greatly prioritized, amply resourced, and staffed and advised by high-profile communication "experts" and consultants; an intense daily (sometimes hourly) competition between those parties to dominate news headlines and bulletin running orders; and an increasing "mediatization" of the overall political communication process, in which actors substitute "media logic" for "political logic" in their policy making and publicity operations, tailoring their public communications to journalists' news values, work routines, and professional cultures (Mazzoleni and Schulz 1999; Esser and Strömbäck 2014).

The emergence of a new media ecology - particularly a news ecology - domestically and globally - is another source of pressure with which the BBC must contend. This has created a new range of platforms and channels, through which civic information circulates. It has also enabled the generation of different "media", varying in size and geographical coverage but innovative in their approaches to the provision of information about political events and ideas.

Meanwhile, the BBC's relations to government have arguably altered to its disadvantage. Whereas in former times the civil service could be regarded as broadly sensitive and sympathetic to the constitutional position of the BBC, especially its independence, it too "has changed greatly in recent years", says historian of the BBC, Seaton (2016). According to her, "fantastically over-stretched", the UK civil service has been "denuded of resources"; "stripped of a policy-making in favour of a man- 
agerial role"; and is "afraid to say booh to ministers". Its public communications tasks have shifted from strictly informational to more propagandistic ones (Garland 2015). Responsibility for dealing with the Corporation has been transferred from the Home Office, a major department of state, where big hitters would have been in charge (some of them pro-BBC politicians, such as Willie Whitelaw and Douglas Hurd in the past), to a Department of Culture, Media and Sport, from which defense of the BBC faith might be less assured. And the long-standing practice of preceding Charter renewal by the institution of "periodic, intensive and comprehensive reviews" of BBC and broadcasting performance generally "by independent publicly appointed committees", composed of individuals from a range of cultural perspectives and interests (Blumler and McQuail 1965, p. 187) no longer obtains. Instead in September 2015 the government commissioned a review of the governance and regulation of the BBC from a single individual, Sir David Clementi (2015), with a background not in culture, communications or the media but in banking administration (with Virgin Money and the Bank of England). In sum, according to the Guardian newspaper (April 14, 2016), "All of these informal checks and balances [of the British constitution were] being short-circuited."

This may be related (though motives are obscure in such matters) to another development, which has recently been emerging in some democracies world-wide. Maintenance of themselves in power is inherently challenging and potentially insecure for all governments, formally democratic or not. To rulers, today's challenges may seem yet more formidable and their holds on power shakier and less secure due among other things to:

- Media abundance (making it near-impossible to run a fully state-owned or financed media system),

- Globalization of communication sources (able to expose citizens to alternative points of view),

- Arrival and expansion of the Internet and social media (facilitating the expression and dissemination of alternative viewpoints),

- Sociopolitical fragmentation (diversifying public opinion currents),

- Increased unpredictability of political events.

These may serve to explain the outbreak of a transnational rash of attempts by governments to control the communication sources of power while retaining procedures of periodic elections - e. g. in Turkey, Hungary, Poland, Russia, the Ukraine, Egypt and India. A key proposal in the White Paper, for half the appointments to a new supervisory Board (replacing the BBC Trust), with substantial editorial and cultural responsibilities and powers, to be government-led, could be interpreted as a UK equivalent of that international trend.

On top of all that, the antagonism toward the BBC of much of Britain's national press (e.g. among the Daily Mail, the Sun, the Times, the Telegraph and the Express) has become more virulently outspoken than even in the past, frequently and prominently headlining the occurrence of many alleged failings of the Corporation's organization and performance and arguing strongly for it to be cut down to size. 


\section{The internal context}

In only a year or two before the process of Charter Review was due to begin, a series of internal failures, errors of judgement, extravagances, and signs of confused purpose and direction came to light, giving the press meat to feed on and suggesting that all was not well with BBC management and governance. As Seaton (2016) put it, "The BBC can sometimes get it dramatically wrong." Most damaging were:

- mounting evidence of the Corporation's ignorance of child sex abuses that had been perpetrated, sometimes on its own premises, by one of its most celebrated personalities (Jimmy Savile) and possibly by others,

- on-again, but finally off-again decision-taking over a documentary exposure of the scandal,

- the resignation of a recently appointed Director General (the Trust's selection), partly due to his mishandling of the above-mentioned affair, compounded by his receipt of a sizeable early retirement pay-off,

- disclosure of inordinately high salaries paid to certain BBC executives and talents,

- reports of other sources of inefficiency and waste, indicative of top-heavy overbureaucratization,

- allegations of "a decline and diminution in the civic mission" of BBC news and current affairs, including ratings-chasing priorities; "a drift away from a mixture of sacerdotal and pragmatic approaches to political news toward a more purely pragmatic one, entailing ... a more central role for conventional news values in the selection, ordering, presentation of and interpretive commentary on daily events" (Blumler 2015); and more frequent sharing of the news agendas of the national press, suggestive of a closer integration into its journalistic culture,

- more insistent imputations of BBC news bias by both Conservative and Labour Party activists.

\section{Props of the $\mathrm{BBC}$ cause}

The BBC did not lack defenses against the threat of its radical reorganization, however. One was a high and widely diffused regard for its past traditions (including that of independence) and records of public service excellence.

Another was the continuing popularity of its everyday television and radio programming and a continuing extensive exposure to it (though less so among young people). BBC output reaches $96 \%$ of the British population; two thirds of adults listen to $\mathrm{BBC}$ radio; the audience for $\mathrm{BBC} 1$ television exceeds that for any other available channel; a half of UK adults use $\mathrm{BBC}$ online (data summarised by media policy academic, Harvey 2016).

There was, thirdly, the BBC's strong and close cultural and financial ties to the creative production sector of British television. A substantial proportion of BBC television programming has been commissioned from a large number of independent production companies since the early 1980s. The international appeal and prestige of BBC drama and entertainment were monetary and reputational assets it would be 
folly to jeopardize. In fact, the BBC based a prominent part of its own post-Green Paper argument on such considerations.

Fourthly, the BBC's cause has been vigorously promoted by an array of civicminded non-governmental organizations, some community, some nationally based. These have arranged public meetings, issued responses to the Green and White Papers in memoranda and public pronouncements, circulated messages online, enlisted celebrity support, etc. Most important among these bodies have been The Voice of the Listener and Viewer (which punches above its weight in numbers and funds) as an established participant in broadcasting policy debate; and 38 degrees, a website which regularly emails large numbers of people, alerting them to current developments and exhorting them to sign petitions and to contact their constituency Members of Parliament.

A fifth important source of strength was undoubtedly the prompt appointment of Tony Hall as Director General to whip the BBC into shape after the several fiascoes in which the Corporation had been embroiled. An outstanding Director of BBC News in the 1990s, with an impressive record of a re-establishing leadership of the Royal Opera House in the 2000s, and with a recognized commitment to public service values, Lord Hall's appointment was unanimously welcomed. Not only would he be able to articulate well the case for sustaining the scale, scope and independence of the BBC; in short order, he also set various efficiencies in train, including the elimination of some layers of corporate management and limitations on higher salary payments. And in a move that could be expected to appeal to the more market-minded members of the government, he announced an intention to create a new, large, well-funded and organisationally distinct arm of the corporation: BBC Studios. Employing a large number of producers, this would bid for commissions to make programmes for $\mathrm{BBC}$ channels as well as for commercial services external to the BBC.

But what about that cautionary survival strategy Smith $(1973,1979)$ and Briggs (1979) had noticed? Anything of that kind would be difficult definitively to establish without access to the inner thoughts and workings of BBC executives and journalists. Some signs suggestive of such an approach did seem to emerge, however. For example, it was understood that in autumn 2014, a leading Conservative politician had warned Nick Robinson (then the BBC's Political Editor) that the BBC should watch its step during the 2015 election campaign, bearing in mind its proximity to the forthcoming Charter Review. And in fact, two content analyses did document more frequent coverage of Conservative-favoured issues by BBC News than of Labour ones during that campaign (Cushion and Sambrook 2015; Centre for Research in Communication and Culture 2015).

\section{The White Paper outlined}

Entitled, "A Future for the BBC: A Broadcaster of Distinction", the government's prospectus for the Corporation's Charter from 2017 was not so unfavourable as had been expected and feared in advance. Many of the points of concern raised in the wash of the Green Paper had apparently been resolved in the BBC's favour - 
so much so that a tone of bitter disappointment pervaded the Conservative-leaning press with one paper typically complaining that the government had "bottled it". Sue MacGregor (2016) was relieved that the government had "rowed back" from some of its extreme ideas. In a somewhat over-the-top reaction, Michael Grade (as quoted in Martinson 2016), who in past incarnations had been a BBC channel controller and (briefly) Chairman of its Board of Governors (before it became the Corporation's Trust), a Channel 4 Chief Executive, and an Executive Chairman of ITV, even declared that the BBC had gained "everything it had wanted" from the government's deal.

Reassuring for the BBC was the White Paper's declaration that, even "in a changed and changing world", "There was a continuing role for public service broadcasting" to provide the knowledge a democracy requires; to inspire audiences with expanded horizons; and to satisfy diverse audience needs. The government's regard for the BBC was expressed in fulsome terms: as "one of the nation's most treasured institutions"; with a "central role in the lives of ordinary people in the UK ... and overseas"; and enjoying a level of "trust higher than in many institutions".

Worthy of note too is the White Paper's attempt to formulate and prescribe a public service purpose for the $\mathrm{BBC}$, something which had been reduced to vacuous generalities too often in the past. The "new mission of the BBC" would be "To act in the public interest, serving all audiences with impartial, high-quality and distinctive media content and services that inform, educate and entertain." The key norm here is distinctiveness, a definition of which was drawn from an invocation by a former Trust Chair:

to inform and entertain ... in a way that is original, distinctive, ambitious, ground-breaking, risk-taking, memorable, innovative, creative, stretching, inspirational.

The BBC was therefore enjoined to be "substantially different to other providers across all its services". To retain its "unique status", the White Paper went on:

... the BBC will need to do more to stand apart from the competition across each and every service, both in prime time and overall, and on television, radio and online.

Commissioning Editors "should ask first and foremost ... is this programme sufficiently innovative and high-quality and not where will this feature in the ratings figures in the next week or month."

While fearful of the White Paper's implications for BBC independence Harvey (2016) has itemized its other plus points as follows:

- Charters terms of 11 years (rather than ten as hitherto) to take Reviews out of the five-year electoral cycle,

- Survival of the license fee as the BBC's prime income source (though alternative funding options are to be reviewed in five years' time),

- license fee to be pegged to the rate of inflation for the next five years,

- license fees to be paid by on-demand viewers, even if they do not possess a television set, 
- rejection of top-slicing of license fee income to subsidise public service programming by other providers (except for a designated fund for children's television),

- the embedding of impartiality as an obligation on all licensed broadcasters,

- a promise of extra money for the World Service.

But in two other major areas, the White Paper's proposals are more problematic for supporters of the $\mathrm{BBC}$, although they are open to differing evaluations.

The issue of $\mathrm{BBC}$ independence lies at the heart of the first of these. The government's view is set out at some length in a chapter of the White Paper entitled "Enshrining independence and accountability". The core thrust of the government's argument is that both norms are essential; but that whereas the near-universal demand for $\mathrm{BBC}$ independence has been and continues to be respected, the need to hold the Corporation to account for how it realizes its public purposes has not been effectively met. The government accordingly accepted Clementi's recommendation to establish a single unitary Board (replacing the BBC Trust) to be "collectively responsible for everything the $\mathrm{BBC}$ does, for delivery against the public purposes and other obligations of the Charter and for acting in the public interest". The extent of the intended power and authority of the Board is spelled out in some detail, thus: "The Board as a whole will have responsibility for setting the overall editorial direction and the framework for editorial standards." A "change of culture within parts of the BBC" is required, "which the new Board will need to support as one of its main priorities". It will be involved in "the appointment of senior executives of the BBC". It will ensure that the Corporation's finances are managed and audited "for value for money", taking account of the market impact of its provision. Crucially, at least a half of the appointments to the Board will be "government-led", including its Chair, Deputy Chair and representatives of each of the UK's four nations - England, Scotland, Wales and Northern Ireland. The White Paper contends that the BBC's independence will be assured by this measure because its Management will have half the seats on the Board; it will be a duty of Board members to uphold the Corporation's independence; the appointments will be made with "due transparency and scrutiny"; and "the Director General's independence and final responsibility for the BBC's editorial decisions and creative output" will be guaranteed.

The White Paper's proposals for regulation (as distinct from governance) of the $\mathrm{BBC}$ give rise to the other main area of concern - its relationship to market forces. Ofcom, its regulator, has hitherto been largely a "light-touch" one. It has statistically tracked the devotion of $\mathrm{BBC}$ resources of money and broadcasting time to diverse programme genres. It has monitored the public's assessments of BBC services across time. It has sign-posted more and less reassuring performance trends and derived policy recommendations from them. It has adjudicated on a narrow range of public complaints (not resolved by the BBC in the first instance), chiefly over criteria of harm, offense and inaccurate reporting. Overall its image has been of a body, which has been more interested in the audience member as a "consumer" of broadcasting than as a "citizen" (Lunt and Livingstone 2012). A core focus has been on the impact of the BBC's provision on the commercial sector of broadcasting.

The White Paper envisages a considerably "beefed up" role for Ofcom. Not only will it "be able" hereafter "to consider complaints about all BBC content, 
including accuracy and impartiality in BBC programmes". It would have a regulatory responsibility to ensure conformity to the BBC's editorial standards. It will have a last word on any new or changed services proposed by the BBC Board. Above all, it can regulate the BBC's own commercial activities and hold it to account for its market impact. And when approving the terms of broadcast service licenses, it will be expected to put "a greater focus" on "quantitative metrics", "rather than the more qualitative approach of the existing service licenses". These would comprise a "set of measurable outputs to which the BBC can be held" at each service level. The government also promises in the White Paper to "provide guidance to the regulator on content requirements and performance metrics to set clear policy parameters for the creation of the new regime".

Two other White Paper proposals relate to this area. First, the government demands that all programming (other than news and current affairs) be open to competitive bidding by would-be outside providers - not $50 \%$ of it as had been the case so far. In this connection it also expresses its approval in principle of BBC Studios. Secondly, the BBC will no longer be solely responsible for auditing its finances. In future, the National Audit Office will be charged to undertake comprehensive audits of the BBC's accounts.

\section{The White Paper explained}

How can the decisions that shaped the White Paper be explained? What were the forces and considerations that fed them? The answers are necessarily speculative but perhaps plausible!

There is nothing puzzling about the government's approach to the organisational structure of the BBC. It never wavered from its early intention to refashion BBC government radically. Although nominally independent, the Clementi review seemed almost to have been set up to put forward and argue for that objective. Systematic of the determination was the White Paper's failure even to mention a set of alternative options for BBC governance set out in Moore (2016), a report entitled "Better Protecting BBC Financial Independence", which had been commissioned by the $\mathrm{BBC}$ Trust. Of course the vital issue of BBC independence is bound up in these structural proposals.

But why was the BBC handed a better deal than had been forecast on many other aspects of its future? Three main sets of factors may have been involved.

One was acceptance of the argument that the BBC's place in the creative and artistic sector, including its monetary and "soft power" benefits, was too important to be weakened. In the White Paper's words, "as the UK's largest broadcaster and a well-respected institution, we want the BBC to help boost the UK's creative industries like film and the arts".

A second major source of influence was very likely overwhelming evidence of the British people's appreciation of the BBC and its television and radio programming. This came through loud and clear in the results of a public consultation on the future of the BBC that the Department of Culture, Media and Sport launched in July 2015, closed in October and reported on in March 2016 (Department for Culture, 
Media and Sport 2016b). The approximately 190,000 responses were the "largest ever received in a consultation". Majorities considered that the BBC served its audiences well; that it should continue to be funded by a license fee; even that some expansion of its service could be welcome. A very large majority "indicated that the BBC should remain independent of government, Parliament and Ofcom". Two public consultations conducted by the BBC Trust revealed similar patterns of widespread approval (approximately 40,000 and 11,000 responses, respectively). It would clearly be risky to mess flagrantly with such public sentiment.

Awareness of this may have interacted with a third set of factors inherent in the political situation that prevailed in Britain in the Spring of 2016. Hindsight suggests that commentators may have exaggerated the degree of consensus inside government circles for cracking down hard on the BBC. Although such an attitude was ascribed to Mr. Whittingdale, the facts that his deputy, Ed Vaizey was an avowed "One Nation" Tory, and that neither the Prime Minister nor the Chancellor of the Exchequer had voiced much anti-BBC sentiment in public, had been ignored. Views about how best to reform the BBC may well have been more mixed inside government and the civil service than had been realized. It has been reported that Tony Hall, by all accounts a formidable negotiator, took advantage of this from time to time, going to see Mr. Cameron when sticking points with Mr. Whittingdale were getting stickier! Also relevant may have been the Prime Minister's acute sensitivity to the political and communication winds of the moment - a veritable "self-mediatizer" in Blumler's (2014) opinion. Moreover, the period following the presentation to Parliament of the government's annual budget in mid-March 2016 had been exceptionally difficult for the government, which commanded only a small majority in the House of Commons. A combination of opposition in the House of Lords and among a small but significant number of back-bench Conservative MPs had forced U-turns on two landmark budget policies: to cut expenditure on disability benefits and reduce disabled people's eligibility to receive them at a time when taxation concessions were being granted to corporations and high-income earners; and to remove all primary and secondary schools from local government control, obliging all of them to accept Academy status by 2020. A stinging letter of resignation from the Cabinet by Iain Duncan Smith as Minister for Welfare and Pensions (and a former Leader of the Conservative Party), complaining that political rather than economic reasons lay behind a sequence of cuts in welfare benefits, drew attention to ever-sharpening divisions in leading Conservative circles. These were more evidently pronounced when, while the government was about to embark on a closely fought European Referendum campaign, the concessions over migrants' welfare benefits, which Mr. Cameron had wrung from the European Union, were scornfully dismissed as derisory by his opponents. Altogether, this was not a good time to submit proposals on the BBC that could ignite yet another intra-party and media-amplified storm. 


\section{The White Paper evaluated}

The White Paper does put its finger on a critical weakness of BBC governance: the lack of effective accountability for how it realises its public purposes and a corresponding failure to work out its relationship to editorial independence. Media regulation academic, Peter Lunt (2016), considers that the White Paper makes an important argument for redressing the balance between accountability and independence. The root of the problem lies in the old model of the BBC as an elite disseminator of information, education and entertainment for its audiences, which is anachronistic in a period of long-gone deference to authority. The government's insistence that the $\mathrm{BBC}$ do more to engage members of the public in its affairs was therefore welcome. Apart from its answerability to the Trust, the BBC's prime mechanism of public accountability at present, regional Broadcasting Councils, is mere window-dressing. When a BBC journalist made unfounded allegations about a government dossier of reasons to intervene in Iraq, which were endorsed by BBC News, the Director General and the Governors, there was no place to go to make the Corporation accountable for that. There did not seem to be a body that could rein the BBC in when it got something wrong.

All that said, the White Paper's treatment of these issues is open to criticism on four main grounds.

First, it puts an administrative cart before a definitional horse! It proposes a machinery of accountability without first discussing the meaning of accountability itself. McQuail (2003) thoroughly reviews a large literature, in which diverse treatments of the notion are discussed, alongside related concepts of responsibility, obligation and freedom of publication. Amidst their several expressions, certain essential features of the idea of accountability stand out. It concerns a relationship between two parties - an actor with performance duties and expectations vis-à-vis a body of persons to whom it is answerable for how it has carried them out. The composition of a Board with representatives of both the state and the BBC executive conflates that distinction, however. The "collective responsibility" conferred on it for decisiontaking builds in a confusion of roles. This issue is not merely academic. If the occurrence of differences and conflicts between government and the BBC (sometimes erupting in heated rows) "goes with the territory", can a single unitary Board really be expected to resolve them readily? Might not decisions in such instances tilt the balance in favour of the government of the day irrespective of the merits of the case? As McQuail (2003, p. 298) concludes, when discussing such tensions, "The media cannot easily serve the political system and at the same time hold the government to account to the public for its failings." McQuail (2003, p. 309) also refers to another essential point in stating that, "accountability is clearly not the same as control ... Unlike control, it takes place after the event." But the strong initiatory powers proposed for the new Board seem to ignore that crucial distinction. In the end, the editorial decision-taking supposedly bestowed on the Director General and his colleagues is likely to be narrower and more circumscribed than in the previous regime. Again as McQuail (2003, p. 310) maintains, in all this, "The key question is "who is accountable to whom?"'. If the answer is to the state, then political independence will be nullified. 
Secondly, the White Paper fails to grasp a crux nettle which inheres in its claim that its proposals safeguard, even enhance the independence of the BBC. Neither it nor its parent Clementi Review explicitly mentions or directly addresses the understandable fear that BBC news, falling under the authority of a Board with many representatives of the state, will tend to be slanted in favour of the government of the day or will be perceived to be biased in that way, undermining as a result the national and international trust that it has enjoyed to date. Much turns, it might be said, on how those appointments are made, about which Lunt (2016) was relatively sanguine (while acknowledging there were risks). He points out for example that because the government appoints judges, nobody thinks they are at its beck and call. "A 'great tradition' of how appointments are made to public bodies is often followed", he says, and could be again when the unitary Board is constituted. Against such reassurance, however, is a statement by Sir David Normington, the outgoing head of the Commission for Public Appointments, which vets good practice when appointments to public bodies are made, deploring recent government decisions that will limit its powers and strengthen the claims of government-preferred candidates for consideration. Although the $\mathrm{BBC}$ has accepted the proposal to institute a unitary Board, Tony Hall has expressed its disagreement with aspects of the process of appointments to it, over which the Corporation will be negotiating further with the government.

Thirdly, the new governance and regulatory regime could greatly increase those "external pressures" mentioned by Briggs (1979). In future the BBC will be accountable to three bodies - the unitary Board, the National Audit Office and an augmented power-holding Ofcom, armed with measurable output metrics to assess BBC performance. This may induce organizational caution, be a recipe for "chilling effects" and sideline the goal of making and delivering programmes that are distinctive, innovative, challenging and risk-taking.

Related to this, fourthly, in place of a four-square public service model of the $B B C$, the White Paper seems to envisage a quite mixed one. Although the continuing designation of the $\mathrm{BBC}$ as a public service broadcaster is important, in practice its $\mathrm{BBC}$ of the future will include public service elements (editorial decision making by the Director General and his staff as well as the emphasis on distinctive programming); state broadcasting (as with government-led appointments to the Board); and commercial broadcasting (as with competitive bidding by independent companies for all BBC programme commissions and the BBC Studios idea). In Peter Lunt's (2016) view, all that simply had to happen that way. There were built-in imperatives behind the adoption of each of these elements: the normative desirability of promoting programme distinctiveness; the need to strengthen the BBC's public accountability; and the presence in the expanded communications system of a panoply of commercial providers of content with which the BBC must come to terms. The BBC was inevitably bound to evolve into something like a hydra-headed beast! Lunt (2016) characterises this as "a traditional British compromise". Perhaps so, but it threatens a confusion of purpose and conduct; a thinning and narrowing of the public service component in practice; and the political independence of the BBC. 


\section{To conclude}

To be or not to be independent remains the fundamental and as yet unresolved question about the future of the BBC. If, due to the composition of its supervisory board, its political independence was to be undermined, many of the gains promised in the White Paper could prove illusory. Next steps will include: further BBCgovernment negotiation; production of a draft Charter by the government; a nonbinding parliamentary debate on the terms of that draft; entry on January 1, 2017 into the next 11-year Charter period. At the time of writing (late June 2016), however, due to the Brexit camp's victory in the recent Referendum, all this is now shrouded in uncertainty. An independent BBC, with all its faults, is one of the few institutions in Britain that could help its people to understand and grapple with the many problems to be faced in the future. It remains to be seen whether the new UK government under Prime Minister May will respect or put paid to such a prospect.

Acknowledgements I am deeply indebted to colleagues and contacts who in interviews, conversations and comments on early drafts of this article enriched its analysis. They included in particular Timothy Garton Ash, Ric Bailey, Stephen Barnett, Michael Cockerell, Stephen Coleman, John Corner, James Curran, Sylvia Harvey, Christina Holtz-Bacha, Peter Lunt, Jean Seaton and Granville Williams.

Open access funding provided by University of Leeds.

Open Access This article is distributed under the terms of the Creative Commons Attribution 4.0 International License (http://creativecommons.org/licenses/by/4.0/), which permits unrestricted use, distribution, and reproduction in any medium, provided you give appropriate credit to the original author(s) and the source, provide a link to the Creative Commons license, and indicate if changes were made.

\section{References}

Babbs, D. (2016). The british people must campaign to save the BBC. New Statesman April 2016.

Barnett, S. (2015, June 15). London school of economics media policy project blog.

Blumler, J.G. (2014). Mediatization and democracy. In F. Esser \& J. Strömbäck (Eds.), Mediatization of politics: understanding the transformation of western democracies (pp. 31-41). Basingstoke: Palgrave Macmillan.

Blumler, J.G. (2015). A veteran's reflections on the state of the field (selected). Annual Conference of the Political Studies Association, Chester, November 2015.

Blumler, J.G., \& McQuail, D. (1965). British Broadcasting - its purposes, structure and control. Gazette, $11,166-191$.

Briggs, A. (1979). Governing the BBC. London: British Broadcasting Corporation.

Centre for Research in Communication and Culture (2015). 2015 UK general election news analysis. Loughborough: Loughborough University.

Clementi, Sir D. (2015). A review of the governance and regulation of the BBC. London: Department of Culture, Media and Sport.

Cushion, S., \& Sambrook, R. (2015, May 15). How TV news let the tories fight the election on their own terms. The Guardian. http://www.theguardian.com/media/2015/may/15/tv-news-let-the-toriesfight-the-election-coalition-economy-taxation.

Department for Culture, Media and Sport (2015). BBC charter review (Green Paper). https://www.gov.uk/ government/collections/bbc-charter-review. Accessed: 16 July 2015.

Department for Culture, Media and Sport (2016a). A BBC for the future: A broadcaster of distinction (White Paper). https://www.gov.uk/government/publications/a-bbc-for-the-future-a-broadcaster-ofdistinction. Accessed: 12 May 2016.

Department for Culture, Media and Sport (2016b). BBC charter review public consultation. https://www. gov.uk/government/uploads/system/uploads/attachment_data/file/504099/BBC_Charter_Review_ Public_Consultation-_Summary_of_Responses.pdf. Accessed: 1 March 2016. 
Edwardes, C. (2015, March 9). "When I left it felt like a huge relief. My life went from black and white to Technicolor": James Purnell on impending fatherhood and why he had to get out of politics Evening Standard. http://www.standard.co.uk/lifestyle/london-life/when-i-left-it-felt-like-a-huge-relief-mylife-went-from-black-and-white-to-technicolor-james-10095479.html.

Enders Analysis (2015). PSB at risk in the world. https://www.dropbox.com/s/dfhhv7kr1m9af7g/PSB \%20at\%20risk\%20in\%20the\%20world\%20\%5B2015-083\%5D.pdf?dl=0. Accessed: October 2015.

Esser, F., \& Strömbäck, J. (2014). Mediatization of politics: understanding the transformation of western democracies. Basingstoke: Palgrave Macmillan.

Garland, R. (2015). Between media and political power: perceptions of government intermediaries caught in the cross-field. International Journal of Press/Politics Conference. Oxford: Reuters Institute for the Study of Journalism.

Hallin, D.C., \& Mancini, P. (2004). Comparing media systems: three models of media and politics. Cambridge: Cambridge University Press.

Hanretty, C. (2011). Public broadcasting and political interference. Abingdon: Routledge.

Harvey, S. (2016, May 31). Interview with author.

Ianucci, A. (2016, May). Contribution to royal television society forum on the future of the BBC.

Ingham, B. (1991). Kill the messenger. London: Harper Collins.

Kelly, M. (1983). Influences on broadcasting policies for election coverage. In J. G. Blumler (Ed.), Communicating to voters: television in the first european parliamentary elections (pp. 65-82). London: Sage.

Lunt, P. (2016, May 25). Interview with author.

Lunt, P., \& Livingstone, S. (2012). Media regulation: governance and the interests of citizens and consumers. Los Angeles: Sage.

MacGregor, S. (2016). Personal communication.

Martinson, J. (2016, May 22). Michael Grade: “The BBC luvvies made idiots of themselves". The Guardian. http://www.theguardian.com/media/2016/may/22/michael-grade-bbc-luvvies-recipes.

Mazzoleni, G., \& Schulz, W. (1999). "Mediatization" of politics: challenge for democracy? Political Communication, 16, 247-261.

McQuail, D. (2003). Media accountability and freedom of publication. Oxford: Oxford University Press.

Moore, M. (2016). Better protecting the financial independence of the BBC: an exploratory report for the $B B C$ trust. London: King's College.

Naughton, J. (2016, May 15). Here is the news - but only if Facebook thinks you need to know. The $O b$ server. https://www.theguardian.com/commentisfree/2016/may/15/facebook-instant-articles-newspublishers-feeding-the-beast.

Patten, C.F. Lord of Barnes (2016). The future of the BBC. Reuter's institute lecture. Oxford: Oxford University.

Perloff, R. M. (2015). Mass communication research at the crossroads. Mass Communication and Society, $18,532-556$.

Plunkett, J. (2016, March 11). Mark Rylance: "No company other than BBC could have made Wolf Hall”. The Guardian. http://www.theguardian.com/media/2016/mar/11/mark-rylance-no-companyother-than-bbc-could-have-made-wolf-hall.

Plunkett, J. (2016, May 3). Sir David Attenborough warns against playing "fast and loose" with BBC. The Guardian. https://www.theguardian.com/tv-and-radio/2016/may/03/david-attenborough-warnsagainst-playing-fast-and-loose-bbc.

Seaton, J. (2015). Pinkoes and traitors: the BBC and the nation 1974-1987. London: Profile Books.

Seaton, J. (2016, May 24). Interview with author.

Smith, A. (1973). The shadow in the cave: the broadcaster, the audience and the state. London: George Allen \& Unwin.

Smith, A. (1979). Britain: the mysteries of a modus vivendi. In A. Smith (Ed.), Television and political life: studies in six european countries (pp. 1-40). London: Macmillan.

Prof. Jay G. Blumler is an Emeritus Professor of the Social and Political Aspects of Broadcasting at the University of Leeds/UK and an Emeritus Professor of Journalism at the University of Maryland/USA. 